\title{
DROPLETS FROM THE PLANKTON NET XXI. -WHITE SHELLS OF IANTHINA PROLONGATA BLAINVILLE-
}

$\operatorname{AUTHOR(S):~}$

Tokioka, Takasi

\section{CITATION:}

Tokioka, Takasi. DROPLETS FROM THE PLANKTON NET XXI. -WHITE SHELLS OF IANTHINA PROLONGATA BLAINVILLE-. PUBLICATIONS OF THE SETO MARINE BIOLOGICAL LABORATORY 1966, 14(1): 17-19

\section{ISSUE DATE:}

1966-04-25

URL:

http://hdl.handle.net/2433/175425

RIGHT: 


\title{
DROPLETS FROM THE PLANKTON NET XXI. WHITE SHELLS OF IANTHINA PROLONGATA BLAINVILLE ${ }^{13}$
}

\author{
TAKASI TOKIOKA \\ Seto Marine Biological Laboratory
}

The fishermen of this vicinity were annoyed by the drop in price of mackerel and jack mackerel caught so richly in the coastal waters of this area after the end of August. Probably this was caused by the disappearance of the cooler coastal water mass and the approach of the warm water current toward shore. On Sunday afternoon, September 5, 1965, at the end of his summer vacation my son, Takasi, Jr., found a number of pleustonic animals were just being stranded on the northern sand beach of the laboratory. Being helped by the small boy, Chihiro Nishimura, he gathered most of them and brought the collection to me for observation. This collection included 643 janthinas, 62 portuguese-men-of-war, 3 velellas and a considerable number of porpitas. The last members were less than $38 \mathrm{~mm}$ in diameter and mostly heavily damaged. Velella was less than $23 \mathrm{~mm}$ in length and the sail was stretched from the left above to right below (NW to SE). Of 62 physalias 56 were right-handed individuals, while the other 6 were left-handed and very small, less than $19 \mathrm{~mm}$ in length of pneumatophore.

Of 643 janthinas, 630 were Ianthina prolongata Blainville (= globosa SwainSON), 9 were I. umbilicata D'ORBIGNy (= globosa BlainviLle), and 4 were I. janthina (LiNNé). Four shells of $I$. janthina were all young shells, $4 \mathrm{~mm}$ high by $6 \mathrm{~mm}$ wide to $9 \mathrm{~mm}$ high by $11 \mathrm{~mm}$ wide, and of the flattened form known generally in this country by the name Ianthina balteata ReEve. Shells of I. umbilicata were $6 \mathrm{~mm}$ high by $6 \mathrm{~mm}$ wide to $11 \mathrm{~mm}$ high by $10 \mathrm{~mm}$ wide.

Shells of $I$. prolongata were $6 \mathrm{~mm}$ high by $7 \mathrm{~mm}$ wide to $29 \mathrm{~mm}$ high by $27 \mathrm{~mm}$ wide. The colouration differs considerably from specimen to specimen, but there is generally seen the trend toward fading of the colour with the increase in shell size. Smaller shells are most frequently purplish throughout, leaving a white belt along the suture, while in the larger specimens of $I$. prolongata the shell surface under the water in the living state on the sea surface, which includes the whole spire and the upper side of the body whorl, becomes much paler than the underside of the last whorl exposed to the light. On the underside of the body whorl, the purplish colour is especially deep in the proximal half of the whorl. The above mentioned fading may

1) Contributions from the Seto Marine Biological Laboratory, No. 449.

Publ. Seto Mar. Biol. Lab., XIV (1), 17-19, 1966. (Article 3) 
rarely occur on smaller shells and contrarily some larger shells may retain the deep colouration characteristic of the smaller shells. Thus smaller shells resemble very closely those of $I$. umbilicata. However, the young of the two species can be distinguished from each other by the fact that in $I$. umbilicata the white belt along the suture is generally narrower and more sharply defined. Also in $I$. umbilicata the shell has a rather bluish hue throughout, while in $I$. prolongata the shell is a little pinkish. In $I$. umbilicata the spire is higher, the contour of respective whorls of the spire shows less curvature and the keel, though very narrow, is much more distinctly defined than in I. prolongata. These features may be helpful in identifying exactly shells of these species with broken apertures.

It was most strange that in this population there were found thirteen whitish shells of $I$. prolongata. These shells are $9 \mathrm{~mm}$ high by $9 \mathrm{~mm}$ wide to $18 \mathrm{~mm}$ high by $16 \mathrm{~mm}$ wide in size and quite the same in appearance as the usual coloured shells, excepting their lack of colour for the most part. They are wholly whitish throughout the spire and the upper surface of the body whorl but lightly purplish at the protoconch except for the $11 \mathrm{~mm}$ high by $10 \mathrm{~mm}$ wide shell in which the protoconch is quite colourless. On the underside of the body whorl, only the small limited area near the proximal end of the columella is faintly coloured purplish. The animal body of $I$. prolongata is generally coloured light purplish, while it is quite whitish for individuals with white shells. When I examined the collected fresh specimens I thought at first sight that those individuals with whitish shells had been dead for at least several hours. But really they were still alive and ejected the purplish ink from the mantle cavity when given strong stimulation in handling them.

When the whole collection of shells is arranged by colouration from deep to light, it may be noticed with surprise that the group of whitish shells seems rather isolated from the others, with scarcely any intermediate shells showing the gradual fading. Moreover, Dr. R. BIERI told me that in handling many shells for measurements he felt that the white shell of $I$. prolongata seemed more fragile and thinner than the coloured ones. Possibly this might be a genetical race, although it cannot be an albino as some faint colour patches are still remaining.

Again on Friday afternoon of November 5, and some subsequent days, other swarms of janthinas were stranded on the same beach. These groups consisted chiefly of $I$. prolongata, but included more $I$. balteata than in the former case; I. umbilicata was quite insignificant again. Some Porpita and a few Velella and Physalia, a considerable number of Glaucus and some Lepas anatifera were found associated with Ianthina. In these cases only three white shells were included. They were from $8 \mathrm{~mm}$ high by $8 \mathrm{~mm}$ wide to $24 \mathrm{~mm}$ high by $23 \mathrm{~mm}$ wide. 
For these notes I wish to express my hearty thanks to Dr. R. BIERI and Mr. H. Tanase for their kindness in offering me the data.

\section{REFERENCES}

Laursen, D. (1953): The genus Janthina. Dana Report, Vol. VI, No. 38, 40 pp., 1 pl., 41 textfigs.

OKutani, T. (1957): Holoplanktonic Gastropoda in the "Kuroshio" area, south of Honshu, May 1955. Rec. Oceanogr. Wks. Japan, Spec. No. 1, pp. 134-142, 3 text-figs.

WILson, D. P. (1958): On some small Janthina janthina (L.) stranded on the Isles of Scilly, 1957. J. mar. biol. Assoc. U. K., Vol. 37, No. 1, pp. 5-8, 1 text-fig.

WILson, D. P. and M. A. WiLson (1956): A contribution to the biology of Janthina janthina (L.). J. mar. biol. Assoc. U. K., Vol. 35, pp. 291-305, Pl. I, 2 text-figs., 2 tables. 